Historic, Archive Document

Do not assume content reflects current scientific knowledge, policies, or practices. 



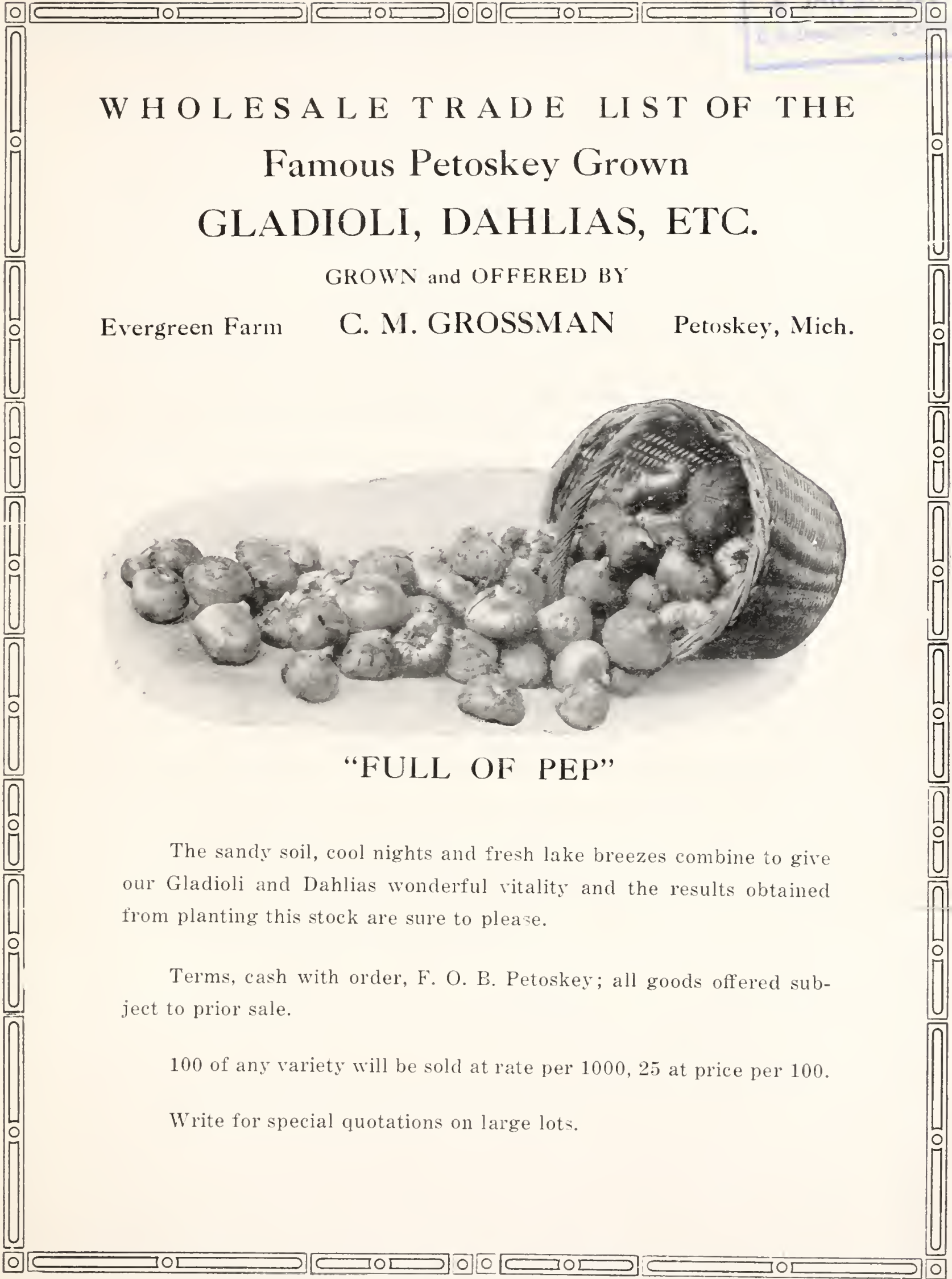




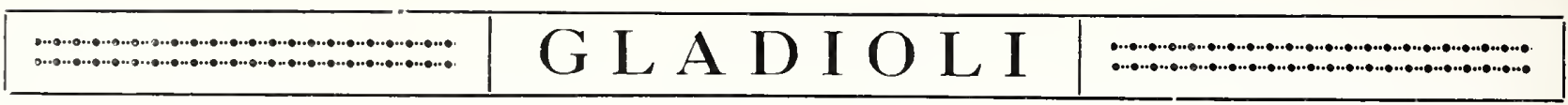

\begin{tabular}{|c|c|c|c|c|c|c|}
\hline & & & & & & \\
\hline & No. 1 & No. 2 & No. 3 & No. 4 & No. 5 & No. 6 \\
\hline Autumn Queen & $\$ 20.00$ & $\$ 16.00$ & $\$ 12.50$ & $\$ 9.00$ & $\$ 6.00$ & $\$ 4.00$ \\
\hline America ......... & 12.00 & 10.00 & 8.00 & 6.00 & $-\ldots$ & $\ldots$ \\
\hline Alice Tiplady & 册 & 32.00 & 25.00 & 20.00 & 16.00 & - \\
\hline Arizona & 20.00 & 16.00 & 12.50 & 10.00 & 8.00 & 6.00 \\
\hline Bertrix & 30.00 & 24.00 & 18.00 & 14.00 & 10.00 & 7.00 \\
\hline Baron Hulot & 40.00 & 32.00 & $-\ldots-\ldots$ & & …-- & 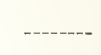 \\
\hline Evelyn Kirtland & 30.00 & 24.00 & 20.00 & -..-- & & \\
\hline Florist's Fancy Mixed & 15.00 & 12.00 & 10.00 & 7.00 & -..--- & -n \\
\hline Flora & 40.00 & 32.00 & 25.00 & 20.00 & -...-- & -... \\
\hline Gretchen Zang & 25.00 & 20.00 & 16.00 & 12.00 & 9.00 & 6.00 \\
\hline Gaiety ....... & 30.00 & 24.00 & 20.00 & 16.00 & 12.00 & 9.00 \\
\hline Halley & 20.00 & 16.00 & 12.50 & 10.00 & 7.00 & 5.00 \\
\hline Helen Franklin & 30.00 & $2 \pm .00$ & 18.00 & 14.00 & 10.00 & 7.00 \\
\hline Jean Dieulafoy & 30.00 & 24.00 & 18.00 & 14.00 & 10.00 & 7.00 \\
\hline Le Marechal Foch & 20.00 & 16.00 & 12.00 & 9.00 & 6.00 & 4.00 \\
\hline Lily White & 25.00 & 20.00 & 16.00 & 12.00 & 9.00 & 6.00 \\
\hline Maiden's Blush & 40.00 & 32.00 & 25.00 & 20.00 & 16.00 & 10.00 \\
\hline Pendleton & 20.00 & 16.00 & 12.00 & 9.00 & 6.00 & 4.00 \\
\hline Peace & 20.00 & 16.00 & 12.00 & 9.00 & 6.00 & 4.00 \\
\hline Prince of Wales & 30.00 & 24.00 & 18.00 & 12.00 & 9.00 & 6.00 \\
\hline Panama & 20.00 & 16.00 & 12.00 & 9.00 & 6.00 & 4.00 \\
\hline Pink Perfection & 40.00 & 32.00 & 25.00 & 20.00 & 16.00 & 10.00 \\
\hline Primulinus Hybrids & 12.00 & 10.00 & 7.00 & 5.00 & 3.00 & \\
\hline 1910 Rose & 30.00 & 24.00 & 18.00 & 14.00 & & ------ \\
\hline Schwaben & 25.00 & 20.00 & 16.00 & 12.00 & $-\cdots-$ & - \\
\hline War & 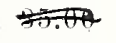 & $\because 8.00$ & 22.00 & 16.00 & & $-\ldots$ \\
\hline
\end{tabular}

Bulblets of many of the above can be supplied, write for prices.

LE MARECHAL FOCH:- Several years' experience has proven this to be one of the very finest for foreing and all around Florist's flower; it is one of the best selling "Glads" on the market, extra early, very large flower, strong grower and blooms fine from all sizes of bulbs; I have a very fine and large stock of this variety and will be pleased to quote special prices on large lots of blooming sizes or planting stock.

MAIDEN'S BLUSH and ALICE TIPLADY:--Desarve special mention as very superior forcing varieties, the very best of the "Prims," most beautiful crlors and very strong growers and both will produce 150 spikes per 100 bulbs; some growers report three spikes to the bulb of Maiden's Blush. Geenhouse men should surely iry these two.

FLCRIST'S FANCY MIXED:-For a number of years this has been giving splendid satisfaction; it is made up of a number of choice named varieties and some fine seedlings of my own crossing; write for special price or. lots of 5,000 to 10,000 or more.

PRIMULINUS HYBRIDS:-All who grow Glads for cut flowers should try these; they come in all shades of pink and yellow, are extremely early and all sizes produce fine and graceful spikes.

I wish to thank my many customers for the fine business they have given me and for the good words they have spoken for the products of "Evergreen Farm." 


(

PER 100

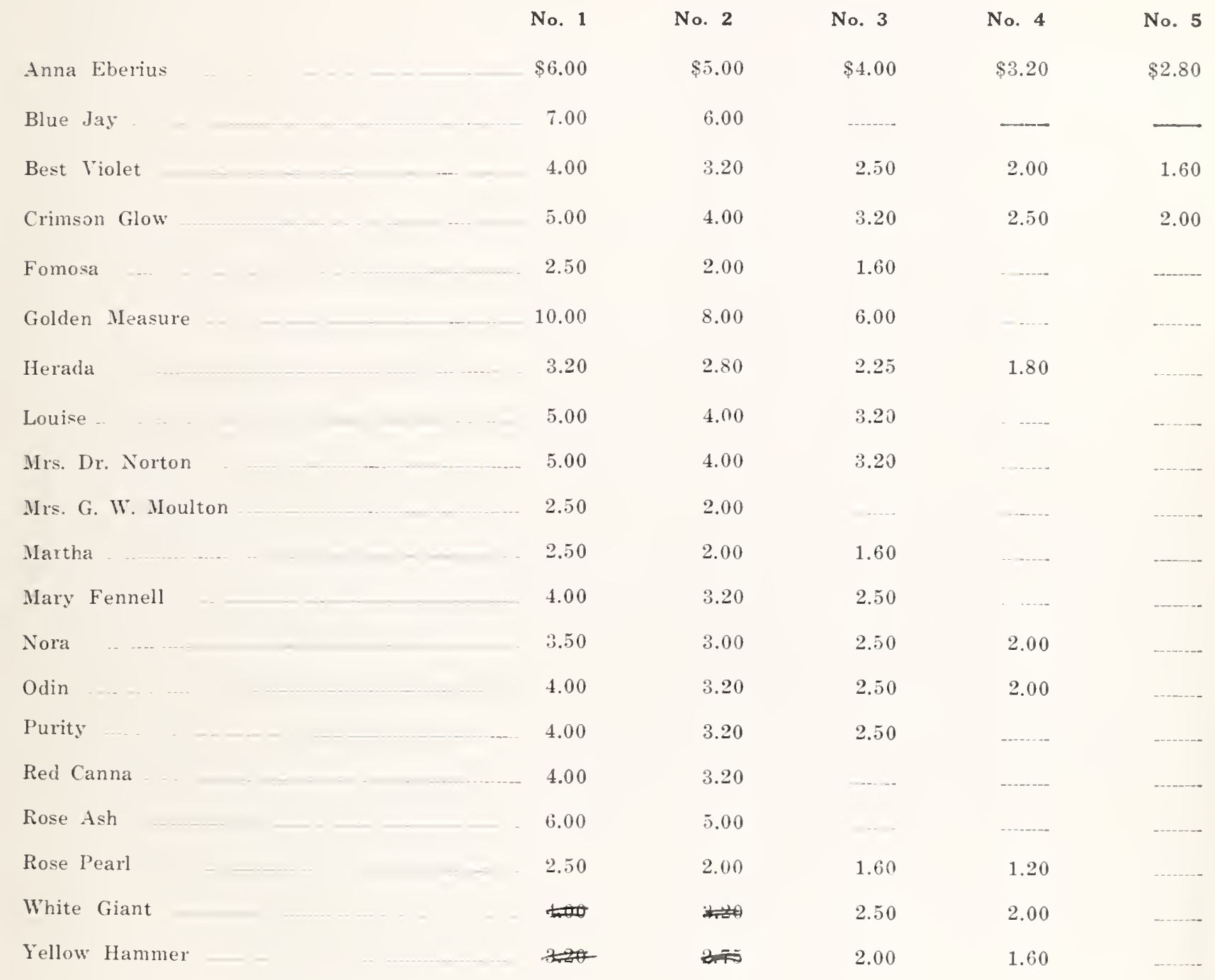

The following priced bv the Dozen:

$\begin{array}{rrlrr}\text { No. } 1 & \text { No. } 2 & & \text { No. } 1 & \text { No. } 2 \\ 1.00 & \$ .80 & \text { Conspicuous } & \$ 1.00 & \$ .80 \\ 1.50 & 1.20 & \text { Hazel Grossman } & 1.00 & .80 \\ 6.00 & 5.00 & \text { Primulinus King } & .75 & .60 \\ 1.00 & .80 & \text { Purple Glory } & 6.00 & 5.00 \\ 1.00 & .80 & \text { Hary Pickford } & 1.00 & .80 \\ 2.00 & 1.60 & \text { White Ruffled } & 1.00 & .80 \\ .75 & .60 & \text { Lovliness } & 1.00 & .80\end{array}$




\section{A SELECT LIST of SOME of THE BEST DAHLIAS}

\section{At prices quoted, Dahlia Roots are sent prepaid and at time for planting out. One-half dozen at dozen rates.}

\section{NO ORDER FILLED FOR LESS THAN 50 CENTS.}

CHANTENAY - Peony Flowered-A wonderful new dahlia and one of the most strikingly beautiful flowers ever grown, a new color in dahlias, a light salmon pink shading to lighter at edge of petals, very long strong stems, making it very fine for cutting.

Each $75 \mathrm{c}-$ Doz. $\$ 6.00$

MADAM VAN LOON - Decorative-Another extra fine new one, a most beautiful shade of red, a free bloomer of large flowers on long stiff stems and a splendid keeper when cut. Each $75 \mathrm{c}-$ Doz. $\$ 6.00$

JULIANA-Peony Flowered-A grand white and very prolific bloomer. large finely shaped flowers on long strong stems, a sure winner as a cut flower.

Each $30 \mathrm{c}$-Doz. $\$ 3.00$

BIANCA-Cactus-A new hybrid cactus of wonderful size and form, color is nearly white overlaid with soft mauve pink, a free bloomer with strong stiff stems, have had specimens eight incres across.

Each $50 \mathrm{c}-$ Doz. $\$ 4.50$

MINA BURGLE-Decorative-One of the very best, a very large flower of the richest cardinal red freely produced on long stiff stems, a strong grower.

Each $40 \mathrm{c}-$ Doz. $\$ 4.00$

QUEEN ELIZABETH-Peony Flowered-The finest dahlia in its class, produces large flowers very freely of a beautiful rosy lavender or mauve on long strong stems, extra good keeper as a cut flower, a very strong grower with many long branches. This should be in every collection. Each $40 \mathrm{c}-$ Doz. $\$ 4.00$

KING OF THE AUTUMN-Decorative-A wonderful variety, the shade is quite new, buff, yellow and terra cotta suffused through it; a well formed flower of great substance carried on a tall, strong stem; will keep a week after being cut.

Each $75 \mathrm{c}-$ Doz. $\$ 8.00$

Bî́CísAi-Decorative-A clear golden orange shading to red in the center; a large and free flowering variety and very deep from front to back.

Each $40 c-$ Doz. $\$ 4.00$

COUNTESS OF LONSDALE-Cactus-Salmon pink and amber; blooms freely and is one of the very best for cutting.

Each $25 \mathrm{c}-$ Doz. $\$ 2.50$

A. D. LAVONI-Show-Soft pink, very pleasing color and the most perfect formed of its type in existence.

Each $15 \mathrm{c}-$ Doz. $\$ 1.65$

JAPANESE IRIS-This is the most showy and beautiful of all the Iris family and comes into bloom after all other varieties are gone; comes in all shades from white to dark blue and purple, flowers from six to eight incres across and last for some time after being cut. I have these in ten varieties. Good strong divisions.
JACK ROSE-Decorative-Brilliant crimson red; one of the best for garden or cutting.

Each $15 c-$ Doz. $\$ 1.65$

SYLVIA-Decorative-Deep pink tinting to flesh pink at center; large, perfect flower on long stiff stems; an old well tried variety and still one of the leading florists' varieties for cutting. Each $15 \mathrm{c}-$ Doz. $\$ 1.65$

BLACK BEAUTY - Decorative-A very strong grower; often six feet or more tall, surmounted with very large maroon colored flowers on long stems; a superb variety.

Each $15 \mathrm{c}-\mathrm{Dz} . \$ 1.65$

DOAZEN-Decorative-Rich fiery red flowers of great size, often eight inches across; a grand variety.

Each 25c-Doz. $\$ 2.50$

ROSE PINK CENTURY-Single-The largest and best deep pink; enormous flowers on long stems.

Each 20c-Doz. $\$ 2.25$

ECKFORD CENTURY - Single-A beautiful white, blotched and striped with crimson, long stems.

Each $20 \mathrm{c}-$ Doz. $\$ 2.25$

HORTULANUS WITTI - Decorative - Very large pure white flowers, one of the very best.

Each $25 \mathrm{c}-$ Doz. $\$ 2.50$

YELLOW DUKE-Decorative-Canary yellow, quilled petals; a fine flower on long stems.

Each $25 \mathrm{c}-$ Doz. $\$ 2.25$

JUMBO-Decorative-Deep red shaded maroon; one of the most prolific varieties in the list, always in bloom.

Each $15 \mathrm{c}-$ Doz. $\$ 1.65$

DELICE-Peony Flowered-One of the most beautiful in the list; a delicate shell kink, large flowers.

Each 20 c-Doz. $\$ 2.25$

JOHN WANAMAKER-Decorative-One of the most beautiful of all dahlias; large, well formed flowers cf clear orchid pink, a very profuse bloomer.

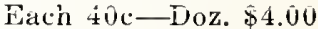

LAVENDER KING-Decorative-This is sure king of all lavender shades; a very free bloomer and very large flowers of a beautiful lively pink.

Each $50 \mathrm{c}-$ Doz. $\$ 5.00$

COREOPSIS - A fi: e yellow blooming perennial; nice strong one-year plants. Doz. $\$ 1.00$-per $100 \$ 8.00$

DIGITALIS-Extra fine and heavy clumps.

Each $50 \mathrm{c}-$ Doz. $\$ 4.00$

HARDY PHLOX_Five colors, assorted.

Each $40 \mathrm{c}$-Doz. $\$ 3.50$

COLORADO BLUE SPRUCE-The rarest and most beautiful of all evergreens; selected specimens. $21 / 2$ to 3 feet, $\$ 3.00$ each; 4 to 5 feet, $\$ 5.00$ each

OTHER EVERGREENS AND SHRUBS-A number of varieties and sizes. Write for prices. 